Ambient Science, 2020: Vol. 07(Sp1); 70-74

DOI:10.21276/ambi.2020.07.sp1.oa08

\title{
Evaluation of Desk Workers' Health Perceptions According to Their Leisure TimeAttitudes and Participation
}

\section{Halime Dinç*, Seniz Karagöz}

Afyon Kocatepe University Faculty of Sport Sciences

Study Area:Afyonkarahisar, Turkey

Coordinates: $38^{\circ} 45.48^{\prime} \mathrm{N} 30^{\circ} 32.32^{\prime} \mathrm{E}$

Key words: Recreation, Health perception, Leisure participation, Leisure attitude.

\section{Introduction:}

Nowadays, many factors such as long shifts, rests with short breaks, income that does not satisfy the labor, competition in the work environment and many similar factors are important problems faced by employees (Avci, 2013). In addition, the inactive lifestyle seen in industrial societies, the overload caused by stress, and unfavorable working standards can negatively affect people's psychological, social and physical health (Solak, 2012). Dökmen (2003) revealed that working life is a factor affecting depression and the difficulties it contains affect the psychological health of individuals. As can be understood from this information, there are many personal and environmental

\section{Abstract}

Occupational disadvantages of desk workers who are exposed for a long sitting periods during working hours cause them to live a sedentary lifestyle. A sedentary lifestyle negatively affects the health of desk workers in physical, physiological, social and psychological aspects. This study is to determine the relationship between leisure attitude, participation in leisure time and perception of health; to reveal the effects of leisure attitudes and leisure time participation on health perceptions. Relational scanning model was used in the research by including the desk workers working in public and private institutions $(n=434)$. A questionnaire form consisting of personal information form, health perception scale, leisure time participation scale and leisure attitude scale was used as data collection tools in the study. It was revealed that the leisure time attitudes of the participants did not have a statistically significant effect on health perception, but their leisure participation had a statistically significant effect on the perception of health. It was found that leisure time attitude alone did not have an effect on health perception, but the interaction of leisure time participation and leisure time participation mediator variable had a significant effect on health perception. As a result, it was reveled that the leisure time attitudes, leisure participation and health perceptions of the participants were above the average score. A positive correlation was found between leisure time attitude and leisure participation. In addition, it was concluded that leisure time attitude affects perception of health together with the leisure time participation tool variable. It is thought that the results of this descriptive research will constitute a reference to experimental studies.

factors that negatively affect the health of employees today. One of these factors is the sedentary lifestyle. Living conditions of the present time limit people's range of motion. Today, many people have to work by sitting down during the day, and they spend most of their non-working time watching television or sitting in front of the computer for a long time (Akyol et al., 2008). Occupational disadvantages of desk workers who are exposed to long sitting periods during working hours cause them to live a sedentary life. Working conditions together with a sedentary lifestyle negatively affect the physical, physiological, social and psychological health of desk employees. 
While people's health-related behaviors affect their health status, attitudes, beliefs, and perceptions play an active role in the development of these behaviors (Diamond et al., 2007). The individual tends to act in line with the attitude developed in the direction of his perception. While perceptions turn into attitudes, these attitudes form the basis of desired behaviors in the future (Özdevecioglu, 2003). The perceptions of people about leisure time and attitudes developing in this direction will determine their participation in leisure activities. Leisure attitude (LA) and assessment skills of people is a phenomenon that starts at an early age and continues to change throughout adolescence, youth and adulthood (Hoff \& Ellis, 1992). Individuals with high leisure perception and attitude take part in positive behavioral activities in order to spend their time effectively and efficiently (Aslan \& Cansever, 2007). Participation in leisure activities (LP) will affect the mental and physical health and health perception of the individual. Frey et al. (1993) noted that the transformation of people's positive attitudes into positive behaviors is affected by many factors such as society, culture, economy and education. Furthermore, in connection with technological developments, working conditions will play a decisive role for time management, leisure time attitudes and behaviors, as well as health of individuals. In this case, it is thought that the health perception of desk workers will be affected by leisure attitudes and behavior. Although there have been studies on leisure time attitude, health perception and recreational participation, no studies investigating the relationship between these three phenomena have been found. This study would be the first in the field to study both the established model and the sample group constructed according to the model. It was aimed to determine the health perceptions, leisure attitudes and leisure time participation of desk workers; to determine the relationship between leisure attitude, participation in leisure time and perception of health and to reveal the effects of leisure attitudes and leisure time participation on health perceptions.

\section{Methodology:}

This study was conducted by taking the relational screening model into its core, which aims to determine the presence or degree of change between two or more variables among the general survey models in accordance with the aims of the study (Karasar, 2013). Participant population consisted of 179 women, 255 men and 434 voluntary desk workers in total, between the ages of $25-65$ and working in public or private institutions in the city centre of Afyonkarahisar. Simple random sampling method was used for the sample selection which is one of the probabilistic sampling method (Table-1). The data were obtained with a questionnaire form consisting of a personal information form, "Leisure Attitude Scale (LAS)", "Leisure Time Participation Scale (LTPS)" and "Perception of Health Scale (PHS)".
Leisure Attitude Scale: in order to determine the participants' attitudes towards leisure time, "Leisure Attitude Scale" (LAS) developed by Raghep and Beard (1982) and adapted into Turkish by Akgül and Gürbüz (2010) was used. The scale consists of 36 items in 5-Likert type. It consists of 3 sub-dimensions, each containing 12 items, defined as "Cognitive", "Affective" and "Behavioral". Construct validity of Leisure Attitude Scale, explanatory factor analysis and confirmatory factor analysis were performed for the working sample group. The subdimensions that emerged as a result of these analyzes were determined as Affective (AF), Internal Cognitive (INTCOG), Exhibited Behavior (EXHB), Desired Behavior (DESB) and Extrinsic Cognitive (EXTRCOG). Cronbach's Alphavalue was determined as 0.951 for this study.

Leisure Participation Scale: the Leisure Participation Questionaire (LPQ) is a 5-point Likert-type scale, which was developed by Procidano and Heller (1983) and whose Turkish validity and reliability was tested by Sevil (2015). The scale consists of 27 items and 4 sub-dimensions. The sub-dimensions of the scale consisted of Recreational Activity (3 items), Cognitive Activity (9 items), Social Activity (9 items) and Productive Activity (6 items), respectively. In the study conducted by Sevil (2015), the total internal consistency coefficient of the Leisure Participation Scale was 0.706 , while the internal consistency coefficient of the sub-dimensions of the scale was 0.724 for Recreational and Cognitive Activity, 0.856 for Productive Activity, and 0.658 for Social Activity.

In this study, construct validity of Leisure Participation Scale, explanatory factor analysis and confirmatory factor analysis were performed for the working sample group. The sub-dimensions that emerged as a result of these analyzes were determined as Recreational and Cognitive (RECCOG), Cultural Activity (CULACT), Pluralist Activity (PLUACT) and Productive Activity (PROACT), but they were used with the abbreviations given here during the study. Cronbach's Alphavaluevalid for this study was determined as 0.865 .

Perception of Health Scale: the "Perception of Health Scale" (PHS), which was developed by Diamond et al., (2007), is a five-point Likert type scale whose original language is English. Its Turkish validity and reliability were made by Kadioglu \& Yildiz (2012). The scale consists of 15 items and four sub-dimensions. Positive statements are items 1, 5, 9, 10, 11 and 14, negative statements are items 2, 3, 4, 6, 7, 8, 12, 13, and 15. Positive statements are scored as "Strongly agree = 5", "Agree = 4", "Undecided = 3", "Disagree $=2$ ", "Totally Disagree = 1". Negative statements are scored inversely. The scale has four sub-dimensions: "Control Center", "Self-Awareness", "Precision" and "Importance of Health". Items 2, 3, 4, 12, and 13 of the scale depending on the control centre dimension, items $6,7,8$, and 15 on the Precision dimension, items 1, 9, and 11 on the Importance of Health dimension and items 5, 10, 14 provide information 
on the Self Awareness dimension. In this study, the structure validity of the Perception of Health Scale, explanatory factor analysis and confirmatory factor analysis was completed for the sample group working at the desk. The sub-dimensions that emerged as a result of these analyzes were determined as Precision dimension (PREDIM), Control Center (CC) and Importance of Health (IMPHEL), and were used in the continuation of the study with the abbreviations given here. Cronbach's Alpha value valid for this study was determined as 0.576 .

Data analysis: within the scope of the study, a questionnaire containing demographic questions and scales was applied to 515 people and relevant data were collected. However, after the erroneous questionnaire forms were removed, the data were analyzed over 434 valid questionnaires. SPSS (Statistical Package for the Social Sciences) package program and LISREL (Linear Structural Relations) package programs were used in the analysis of the obtained data. It was determined that the skewness and kurtosis coefficients of the scores of the sample group of desk workers from PHS, LPQ and LAS were between -1.5 and +1.5 , and it was observed that the data were distributed normally (Tabachnick \& Fidell, 2013). Pearson correlation analysis was used to determine the relationship between scales, and Explanatory Factor Analysis (EFA) was used to determine the sub-dimensions of the relevant scales. Confirmatory Factor Analysis (CFA) was conducted to verify the relationships between sub-dimensions. Finally, Structural Equation Modeling (SEM) was used to model the relationships between scales. Structural Equation Modeling (SEM) is a statistical modelling technique and reveals the cause-effect relationship between the measured and unmeasurablevariables (Sehribanoglu, 2005).

\section{Results :}

\section{Results are summerized in Table 1 to 5 and figure 1 \& 2 .}

While Table-2 is analyzed that although the relationships between PH and LA of desk workers are not statistically significant, they are in a weak negative relationship, on the other hand, there is a statistically significant positive weak relationship between these individuals and LA.

Figure-1 shows the result of SEM established between the LA and LTP of the desk workers and the Perceptions of Health, different from the models previously established for the sub-dimensions of Health Perception. It is seen that the most effective variable on the LTPs of the desk workers is the Recreational Cognitive (RECCOG) variable with a coefficient of 0.93, and the Affective (AFF) variable with a coefficient of 0.97 on their LA. The Control Center (CC) variable shows itself as the most effective variable on health perceptions with an effect of 0.99 .

A 1 unit increase in the LTP of the desk workers causes a decrease of 0.21 on their PH, as can be seen from Table 3, which was found to be statistically significant and the hypothesis was confirmed. Apart from this, a one-unit increase in the LA of the employees causes a decrease of 0.04 on their $\mathrm{PH}$, but when Table 3 is examined, this decrease was not found to be statistically significant.

Table-1: Distribution of Participants as per their Demographic Characteristics and Descriptive Statistics of LA, LTP and PH

\begin{tabular}{|c|c|c|c|c|c|c|}
\hline \multicolumn{2}{|l|}{ Variable } & \multicolumn{2}{|c|}{ Freq. \% } & \multirow{2}{*}{$\begin{array}{l}\mathrm{LA} \\
\frac{\mathrm{x}^{-} \pm \mathrm{SS}}{3.811 \pm 0.53}\end{array}$} & \multirow{2}{*}{$\begin{array}{l}\text { LTP } \\
\mathrm{x}^{-} \pm \mathrm{SS} \\
23.395 \pm 0.597\end{array}$} & \multirow{2}{*}{$\begin{array}{l}\mathrm{PH} \\
\frac{\mathrm{X}^{-} \pm \mathrm{SS}}{3.235 \pm 0.502}\end{array}$} \\
\hline Sex & Fem. & 179 & 41.2 & & & \\
\hline & Male & 255 & 58.8 & $3.806 \pm 0.574$ & $3.192 \pm 0.676$ & $3.214 \pm 0.480$ \\
\hline \multirow[t]{7}{*}{ Age } & $22-26$ & 45 & 10.4 & $3.834 \pm 0.555$ & $3.438 \pm 0.558$ & $3.272 \pm 0.616$ \\
\hline & $27-31$ & 86 & 19.8 & $3.886 \pm 0.565$ & $3.330 \pm 0.614$ & $3.216 \pm 0.509$ \\
\hline & $32-36$ & 84 & 19.4 & $3.816 \pm 0.452$ & $3.216 \pm 0.666$ & $3.231 \pm 0.399$ \\
\hline & $37-41$ & 71 & 16.4 & $3.818 \pm 0.517$ & $3.272 \pm 0.656$ & $3.169 \pm 0.479$ \\
\hline & $42-46$ & 60 & 13.8 & $3.774 \pm 0.541$ & $3.243 \pm 0$. & $3.326 \pm 0.517$ \\
\hline & $47-51$ & 37 & 8.5 & $3.742 \pm 0.556$ & $3.167 \pm 0.694$ & $3.161 \pm 0.475$ \\
\hline & $52+$ & 40 & 9.2 & $3.571 \pm 0.757$ & $3.055 \pm 0.638$ & $3.231 \pm 0.454$ \\
\hline Missing & & 11 & 2.5 & & & \\
\hline Marital & Single & 136 & 31.3 & $3.803 \pm 0.575$ & $3.360 \pm 0.632$ & $3.232 \pm 0.518$ \\
\hline Status & Married & 286 & 65.9 & $3.803 \pm 0.55^{8}$ & $3.207=$ & $3.220 \pm 0.463$ \\
\hline Missing & & 12 & 2.8 & & & \\
\hline Perceived & V.Low & 29 & 6.7 & $3.726 \pm 0.636$ & $3.440 \pm 0.692$ & $3.232 \pm 0.564$ \\
\hline \multirow[t]{4}{*}{ Income } & Low & 75 & $17 \cdot 3$ & $3.821 \pm c$ & $3.216 \pm .6309$ & $3.118 \pm 0.460$ \\
\hline & Average & 205 & 47.2 & $3.848 \pm 0.550$ & $3.295 \pm 0.629$ & $3.260 \pm 0.489$ \\
\hline & Good & 96 & 22.1 & $3.713 \pm 0.515$ & $3.127 \pm 0.639$ & $3.277 \pm 0.479$ \\
\hline & V. Good & 12 & 2.8 & $3.711 \pm 0.741$ & $3 \cdot 377 \pm 0.841$ & $3.151 \pm 0.556$ \\
\hline Missing & & 17 & 3.9 & & & \\
\hline \multirow[t]{2}{*}{ Smoking } & Yes & 186 & 42.9 & $3.857 \pm 0.520$ & $3.268 \pm 0.662$ & $3.190 \pm 0.463$ \\
\hline & No & 240 & $55 \cdot 3$ & $3.75^{8} \pm 0.580$ & $3.263=$ & $3.258 \pm 0.502$ \\
\hline Missing & & 8 & 1.8 & & & \\
\hline Institu- & State & 335 & 77.2 & $3.796 \pm 0.544$ & $3.261 \pm$ & $3.260 \pm 0.487$ \\
\hline tion Type & Private & 61 & 14.1 & $3.900 \pm 0.556$ & $3.300 \pm 0.590$ & $3.132 \pm 0.536$ \\
\hline Missing & & 38 & 8.8 & & & \\
\hline Health & No & 371 & $85 \cdot 5$ & $3.801 \pm 0.538$ & $3.269 \pm 0.642$ & $3.226 \pm 0.497$ \\
\hline His & Yes & 60 & 13.8 & $3.827 \pm 0.650$ & $3.340 \pm 0.699$ & $3.201 \pm 0.448$ \\
\hline Missing & & 8 & 1.8 & & & \\
\hline Regular & Yes & 200 & 46.1 & $3.879 \pm 0.505$ & $3.412 \pm 0.622$ & $3.231 \pm 0.511$ \\
\hline Exercise & No & 228 & 52.5 & $3.736 \pm 0.592$ & $3.153 \pm 0.653$ & $3.218 \pm 0.469$ \\
\hline Missing & & 6 & 1.4 & & & \\
\hline \multirow[t]{4}{*}{ BMI } & Weak & 14 & 3.2 & $3.927 \pm 0.638$ & $3.401 \pm 0.780$ & $3.172 \pm 0.532$ \\
\hline & Normalı & & 38.5 & $3.847 \pm 0.495$ & $3 \cdot 333 \pm 0.651$ & $3.215 \pm 0.492$ \\
\hline & Over & 143 & 32.9 & $3.809 \pm 0.602$ & $3.263 \pm 0.690$ & $3.218 \pm 0.515$ \\
\hline & Obese & 65 & 15.0 & $3.714 \pm 0.585$ & $3.156 \pm 0.591$ & $3.226 \pm 0.443$ \\
\hline Missing & & 32 & $7 \cdot 4$ & & & \\
\hline
\end{tabular}

Table-2: Correlations between PH, LTP and LA Variables

\begin{tabular}{llllll}
\hline Variable & LA & LTP & Variable & LA & LTP \\
\hline LTP & 0.195* $^{*} 1$ & PH & -0.043 & -0.068 \\
\hline
\end{tabular}

**PH: Perception of Health, LTP: Leisure Time Participation, LA: Leisure Attitude

Table-3: Standardized Parameter Estimates (SPE), t Statistics and Hypotheses of the Established Model for LTP, LA and PH

\begin{tabular}{lllll}
\hline Hypotheses & Paths & SPE & t statistics & Result \\
\hline $\mathrm{H}_{1}$ & $(\mathrm{LTP}) \rightarrow(\mathrm{PH})$ & $\mathbf{- 0 . 2 1}$ & $-\mathbf{7 . 4 3}$ & Verified \\
$\mathrm{H}_{2}$ & $(\mathrm{LA}) \rightarrow(\mathrm{PH})$ & $\mathbf{- 0 . 0 2 4}$ & $\mathbf{- 1 . 5 0}$ & Not Verified \\
\hline
\end{tabular}

As per Table-5, it could be said that the model is a suitable model according to all criteria. Also, the values of ? 2 $(46)=127.26 ; ? 2 / \mathrm{df}=2.766<3$ show that it is a suitable model. 

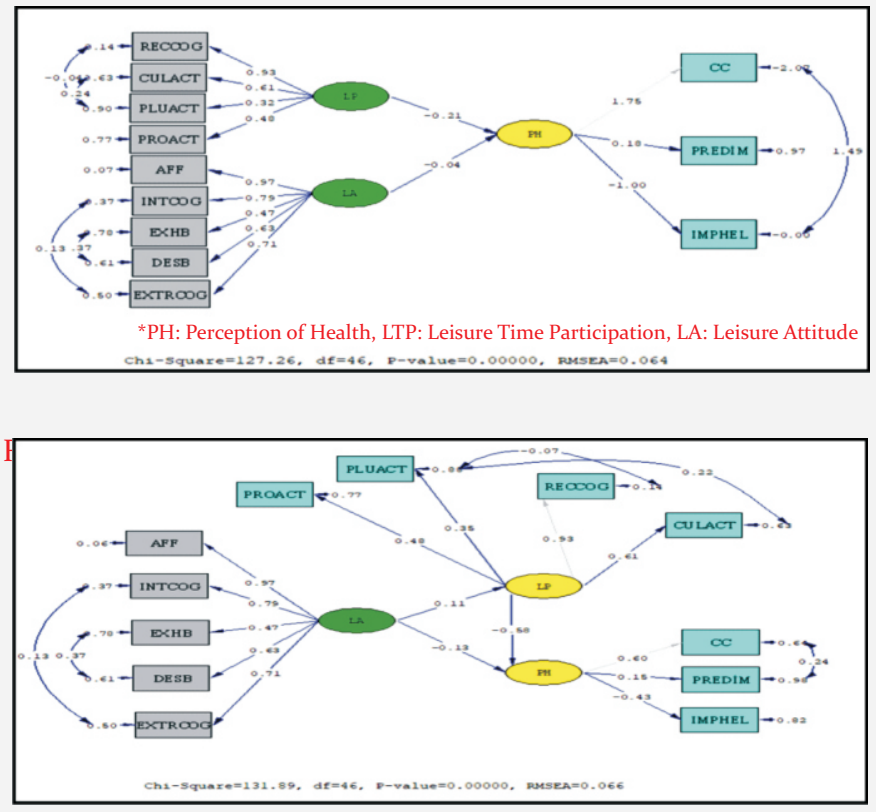

Figure-2: SEM Result Regarding the Relationship with the Regulatory Effect of LTP between LA and PH

In Figure 2, SEM results regarding the regulatory effect of LTP between LA and PH for desk workers are shown. It is seen that the most effective variable on the LTPs of the desk workers is the RECCOG variable with a coefficient of 0.93 , and the variable of AFF with a coefficient of 0.97 on the LAs. On the other hand, CC variable shows itself as the most effective variable with a coefficient of 0.60 on Perceptions of Health.

A 1-unit increase in the LAs of desk workers causes a o.13-unit increase in their PH's and a o.11-unit increase on their LTP, while one-unit increase in their LTP causes a o.58percent decrease on their PH. As can be seen from Table-4, the relationship between LA and LTP and the relationship between LA and PH were found to be statistically significant and the related hypotheses were confirmed, while the relationship between LA and PH was not statistically significant. As a result of the findings, it is possible to say that LTP has a significant regulatory effect between LAand PH.

Table-5: Values of Compliance Criteria for the Established YEM Models

\begin{tabular}{lllllllll}
\hline $\begin{array}{l}\text { Compli. Perfect } \\
\text { Criteria }\end{array}$ & $\begin{array}{l}\text { Acceptable } \\
\text { Match }\end{array}$ & KM & \multicolumn{3}{c}{ KES SON PH } \\
RMSEA & $0<$ RMSEA $<0.05$ & $0.05=\mathrm{RMSEA}=0.10$ & 0.043 & 0.051 & 0.048 & 0.06 \\
RMI & $0.95<\mathrm{NFI}=1$ & $0.90<\mathrm{NFI}=0.95$ & 0.96 & 0.95 & 0.95 & 0.94 \\
NFI & NNFI & $0.97<\mathrm{NNFI}=1$ & $0.95=\mathrm{NNFI}=0.97$ & 0.97 & 0.96 & 0.97 & 0.95 \\
CFI & $0.97<\mathrm{CFI}=1$ & $0.95=\mathrm{CFI}=0.97$ & 0.98 & 0.97 & 0.98 & 0.96 \\
SRMR & $0<\mathrm{SRMR}<0.05$ & $0.05=\mathrm{SRMR}=0.10$ & 0.043 & 0.043 & 0.045 & 0.066 \\
GFI & $0.95<\mathrm{GFI}=1$ & $0.90=\mathrm{GFI}=0.95$ & 0.96 & 0.96 & 0.96 & 0.95 \\
AGFI & $0.90<\mathrm{AGFI}=1$ & $0.85=\mathrm{AGFI}=0.90$ & 0.94 & 0.94 & 0.94 & 0.92 \\
\hline
\end{tabular}

(RMSEA: Root Mean Square Error of Approximation, NFI: Normed Fit Index, NNFI: Non-Normed Fit Index, CFI: Comparative Fit Index, SRMR: Standardized Root Mean Square Residual, GFI: Goodness of Fit Index, AGFI:Adjusted Goodness of Fit Index)
(Resource: Schermelleh-Engel and Moosbrugger, 2003).

Apart from this, when the values given in Table 5 are examined in order to determine the statistical significance of the SEM given in Figure 2, it can be said that the model is a suitable model according to all criteria. Also, the values of ?2 $(46)=131.89 ; ? 2 / \mathrm{sd}=2.867<3$ are other indicators which show that it is a suitable model.

\section{Discussion}

Leisure Time Participation of desk workers shown a statistically significant and negative effect on Health Perceptions. This negative result makes us think that individuals working at a desk are affected by their upbringing, beliefs in their cultural and social environment and a number of other facts. In addition, the fact that the desk workers who participate in recreational activities are individuals with a low perception of health suggests that negative health perceptions create an inclination toward these activities and these individuals participate in leisure time to get out of this perception. Stress negatively affects health and causes people to perceive their health negatively (Kelestimur, 2015). Therefore, it is thought that desk workers may have a low perception of health and tend to direct themselves to recreational activities. In the literature, it is seen that the stress and burnout of work-life are tried to be eliminated by recreational activities (Bauman et al., 2016; Mokaya \& Gitari 2012). In addition, Sudholz et al., (2018) states that desk workers are uncomfortable with their sitting times and this affects their health beliefs. It is seen that the effect of Leisure Attitude on the Perception of Health is not statistically significant. In addition, it was found that Leisure Attitude negatively affected the perception of health. The direct effect of the Leisure Attitudes of desk workers on Health Perceptions is negative, although it is not statistically significant. When the indirect effects of the Employees' Leisure Attitudes on Health Perceptions are examined; it is seen that there is a significant and positive relationship between the Leisure Attitudes of the individuals and their Leisure Time Participation. A significant and negative relationship was also found between Leisure Participation and Perception of Health. It can be said that the leisure time participation of individuals plays a significant regulatory variable between their Leisure Attitude and Health perceptions. As can be seen in Fig.-2, when employees' leisure time participation is considered as a regulatory variable, different from the models given before, it is seen that Recreational and Cognitive participation is the most effective variable on the leisure time participation of employees. While the Leisure Attitudes of the desk workers do not have a direct effect on their Health Perceptions, these attitudes have a significant effect on the Perceptions of Health when taken together with their behaviours. The result that attitudes affect behaviour is consistent with the literature (Alport, 1935; 


\section{ORIGINAL ARTICLE}

Fazio \& Zanna, 1978; Kagitçibasi, 1983; Lee, 2009).

\section{Conclusion and Recommnedation:}

A positive relationship between leisure attitude and participation in leisure activities was revealed. It was found that the relationship between leisure attitude and perception of health was not significant, but there was a significant regulatory effect of health perception in the relationship between leisure attitude and health perception. In line with the results obtained in the study, support should be provided with seminars and training that will ensure the positive development of time management, leisure attitudes and behaviour for Desk workers. Suitable leisure activity participation programs should be prepared for desk employees and necessary support should be given to ensure their participation in leisure activities. Information about short-term in-office activity programs for desk workers who are exposed to long sitting periods should be given and sample exercise programs should be prepared. In addition, it is recommended to include experimental or longitudinal studies in order to determine the status of the existing literature in the field, to guide for similar studies and to examine the current situation in the process. Since the results obtained in this study are within-sample limitation, it is recommended to increase the sample numbers and differences forgeneralized results.

\section{References:}

Akgül, B.M. \& Gürbüz, B. (2010): Bos Zaman Tutum Ölçegi: Geçerlik Ve Güvenirlik Çalismasi. Gazi Beden Egitimi ve Spor Bilimleri Dergisi, 16(1):37-43.

Akyol, A., Bilgiç, B. \& Ersoy, G. (2008): Fiziksel Aktivite, Beslenme ve Saglikli Yasam. Birinci Basim, Klasmat Matbaacilik, Ankara.

Alport, G.W. (1935): Attitudes//Murchison ?. Handbook of social psychology. Pub. by: Worcester.

Aslan, N. \& Cansever, B.A. (2007): Okuldaki Sosyal Etkinliklere Katiimda Ebeveyn Çocuk Etkilesimi Kültürlerarasi Bir Karsilastirma. Ege Egitim Dergisi, 8(1):113-130.

Avci, S. (2013): Farkli mesleklerde çalisan kadinlarin yasam doyumu, is doyumu, tükenmislik ve algilanan cinsiyet ayrimciligi düzeylerinin depresyon ile iliskisinin incelenmesi, Doktora Tezi. Haliç Üniversitesi Sosyal Bilimler Enstitüsü, Istanbul.

Bauman, A., Merom, D., Bull, F.C., Buchner, D.M. \& Singh, M.A.F. (2016): Updating the evidence for physical activity: summative reviews of the epidemiological evidence, prevalence, and interventions to promote "active aging". Gerontologist, 56(2):268-280.

Diamond, J.J., Becker, J.A., Arenson, C.A., Chambers, C.V. \& Rosenthal, M.P. (2007): Development of a scale to measure adults' perceptions of health: Priliminary findings. L. Comm. Psychol., 35(5):557-561.

Dökmen, Z.Y. (2003): Çalisma durumlari farkli üç grup kadinda ruh
Ambient Science, 2020: Vol. 07(Sp1); 70-74 DOI:10.21276/ambi.2020.07.sp1.oa08

sagligi, kontrol odagi inanci ve cinsiyet rolü. Türk Psikoloji Dergisi, 18(51):111-124.

Fazio, R.H. \& Zanna, M.P. (1978): Attitudinal qualities relating to the strength of the attitude-behavior relationship. J. Exp. Soc. Psychol., 14(4):398-408.

Frey, D., Stahlberg, D. \& Gollwitzer, P.M. (1993): Einstellung und Verhalten. Die Theorie des überlegten Verhaltens und die Teheorie des geplanten Verhaltens. In D. Frey, M. Irle (Hrsg.), Kognitive Theorien der Sozialpsychologie, Band I. Bern, Göttingen, Toronto, Seatle.

Hoff, A.E. \& Ellis, G.D. (1992): Influence of agents of leisure socialization on leisure self-efficacy of university students. $J$. Leis. Res., 24(2):114-126.

Kadioglu, H. \& Yildiz, A. (2012): Saglik Algisi Ölçegi'nin Türkçe Çevriminin Geçerlilik ve Güvenilirligi. Turkiye Klinikleri J. Med. Sci., 32(1):47-53.

Kagitçibasi, C. (1983): Insan ve Insanlar. Pub. by: Beta Yayinlari, Istanbul.

Karasar, N. (2013): Bilimsel Arastirma Yöntemi. 25. Pub. by: Baski, Nobel Yayinevi, Ankara.

Kelestimur, H. (2015): Sempozyum 7: Stres, Üreme Fonksiyonlari ve Davranis Türk Fizyolojik Bilimler Dernegi 41. Ulusal Fizyoloji Kongresi, Çanakkale Onsekiz Mart Üniversitesi.

Lee, T.H. (2009): A structural model to examine how destination image, attitude, and motivation affect the future behavior of tourists. Leisure Sci., 31(3):215-236.

Mokaya, S.O. \& Gitari, J.W. (2012): Effects of workplace recreation on employee performance the case of Kenya Utalii College. Int.J. Human. So. Sci., 2(3):176-183.

Özdevecioglu, M. (2003): Algilanan örgütsel adaletin bireylerarasi saldirgan davranislar üzerindeki etkilerinin belirlenmesine yönelik bir arastirma. Erciyes Universitesi Iktisadi ve Idari Bilimler Fakültesi Dergisi, 21:77-96.

Procidano, M.E. \& Heller, K. (1983): Measures of perceived social support from friends and from family: Three validation studies. Am. J. Comm. Psychol., 11(1):1-24.

Ragheb, M.G. \& Beard, J.G. (1982): Measuring leisure attitude. J. Leisure Res., 14(2):155-167.

Sevil, T. (2015): Terapatik rekreasyonel aktivitelere katilimin yaslilarin algiladiklari bos zaman tatmini, yasam tatmini ve yasam kalitesine etkisi. Anadolu ÜniversitesiSaglik Bilimleri Enstitüsü, Yüksek Lisans Tezi,Eskisehir.

Solak, Ö.(2012): Masabasi Çalisanlarinin Masa Basi Egzersizleriyle Fizyolojik Degisimlerinin Ve Saglikli Yasam Biçimi Davranislarinin Incelenmesi. Nigde Üniversitesi Sosyal Bilimleri Enstitüsü,Yüksek Lisans Tezi,Nigde.

Sudholz, B., Salmon, J. \& Mussap, A.J. (2018): Workplace health beliefs concerning physical activity and sedentary behaviour. Occup. Med., 68(9):631-634.

Sehribanoglu, S. (2005): Yapisal Esitlik Modelleri ve Bir Uygulamasi, Yüzüncü Yil Üniversitesi, Fen Bilimleri Enstitüsü, Yüksek Lisans Tezi, Van. 